\title{
Incidencia estacional de mareas rojas en la bahía de Santa Marta y sectores adyacentes, Caribe colombiano
}

\section{Seasonal incidence of red tides in the Bay of Santa Marta and adjacent sectors, Colombian Caribbean}

\author{
Natalia Arbeláez M. *, Julián Franco-Angulo y Luisa F. Espinosa \\ $\begin{array}{lll}\text { (D) } 0000-0002-5162-0336 & \text { (D) } 0000-0002-7626-7911 & \text { (D) } 0000-0003-1452-3104\end{array}$ \\ 1. Instituto de Investigaciones Marinas y Costeras “José Benito Vives de Andréis” (Invemar), Santa Marta D.T.C.H., Colombia.nar_nmc@hotmail.com*; \\ julian.franco@invemar.org.co; luisa.espinosa@invemar.org.co \\ * Autora de correspondencia.
}

\section{RESUMEN}

\begin{abstract}
$\mathrm{C}$ on el propósito de describir las condiciones ambientales y climáticas asociadas con la ocurrencia de seis eventos de mareas rojas entre 2010 y 2017 en Santa Marta (Caribe colombiano), se recopiló la información biológica y físicoquímica obtenida durante estos eventos. Adicionalmente, se consultaron los datos de precipitación y el Índice Oceánico de El Niño (ONI) entre 2010 y 2017. Los resultados mostraron que el dinoflagelado Cochlodinium sp. fue el responsable de tres eventos ocurridos en octubre de 2010, octubre de 2011 y noviembre de 2015, períodos en los que alcanzó densidades máximas de $5 \times 10^{6}$ cél. $\mathrm{L}^{-1}$. Estos eventos se asociaron con un incremento en las precipitaciones y la temperatura superficial del agua de $\operatorname{mar}\left(29,7^{\circ} \mathrm{C}\right)$ y con un descenso en la salinidad $(<35,5)$. El ciliado Mesodinium cf. rubrum fue responsable de otros tres eventos (enero de 2015, enero de 2017 y marzo de 2017), períodos en los que registró concentraciones máximas de 9,2 × $10^{6}$ cél. $\mathrm{L}^{-1}$. Durante estos últimos eventos, no se presentaron precipitaciones y se evidenciaron elevadas concentraciones de nutrientes, incrementos en la salinidad $(>36,6)$ y temperaturas del mar inferiores a $26^{\circ} \mathrm{C}$. Al asociar las ocurrencias de mareas rojas y los valores del índice ONI, se evidenció que las floraciones de Cochlodinium sp. ocurrieron durante años influenciados por eventos climáticos (térmicos) moderados y fuertes $\left(\mathrm{ONI}> \pm 1^{\circ} \mathrm{C}\right.$ ) en tanto que las floraciones de $M$. cf. rubrum se presentaron durante años neutrales (ONI entre 0,5 y $\left.-0,5^{\circ} \mathrm{C}\right)$. Las mareas rojas presentaron un patrón temporal de ocurrencia en la región del Magdalena, influenciadas por la variabilidad climática y ambiental de cada época, sin representar hasta el momento un riesgo para la salud humana.
\end{abstract}

PALABRAS CLAVE: mareas rojas, floraciones algales, variabilidad climática, Caribe colombiano

\section{ABSTRACT}

I $\mathrm{n}$ order to describe the environmental and climatic conditions associated with the occurrence of six red tide events between 2010 and 2017, in Santa Marta (Colombian Caribbean), biological and physicochemical information during these events was collected. Additionally, precipitation data and the Oceanic Niño Index (ONI) between 2010 and 2017 were consulted. The results showed that the dinoflagellate Cochlodinium sp. was responsible for three events that occurred in October 2010, October 2011 and November 2015 , reaching a maximum densities of $5 \times 10^{6}$ cells $\mathrm{L}^{-1}$. These events were associated with an increase in rainfalls and seawater surface temperature $\left(29.7^{\circ} \mathrm{C}\right)$ and a decrease in salinity $(<35.5)$. The Mesodinium cf. rubrum ciliate was responsible for three other events (January 2015, January 2017 and March 2017), recording maximum concentrations of $9.2 \times 10^{6}$ cells L ${ }^{-1}$. During these last events, there was no rainfall and high concentrations of nutrients, increases in salinity $(>36.6)$ and sea temperatures below $26^{\circ} \mathrm{C}$ were evident. Associating the occurrences of red tide events and the ONI index, it was evidenced that Cochlodinium sp. blooms occurred during years influenced by moderate-strong climatic (thermal) events $\left(\mathrm{ONI}> \pm 1{ }^{\circ} \mathrm{C}\right)$ whereas the blooms of $M$. cf. rubrum occurred during neutral years (ONI between 0.5 and $-0.5^{\circ} \mathrm{C}$ ). The red tides presented a temporal pattern of occurrence in the Magdalena region, influenced by the climatic and environmental variability of each period, without representing a risk to human health until now.

KEYWORDS: red tides, algae blooms, climatic variability, Colombian Caribbean

DOI: https://doi.org/10.25268/bimc.invemar.2020.49.2.940 Publicado por INVEMAR

Published by INVEMAR

Este es un manuscrito de acceso abierto bajo la licencia CC

Reconocimiento-No Comercial-Compartir Igual 


\section{INTRODUCCIÓN}

Las mareas rojas son fenómenos naturales que normalmente causan cambios en la coloración del agua como consecuencia del incremento en el tamaño, la densidad o la acumulación de organismos planctónicos pigmentados, entre los cuales se incluyen microalgas, cianobacterias y ciliados microzooplanctónicos. Estos eventos ocurren en diversas partes del mundo y su aparente incremento tanto en frecuencia como en intensidad, en las últimas décadas, es cada vez más evidente a escala global (Sar et al., 2002; Hallegraeff et al., 2004). Algunos estudios indican que son varios los factores que influyen en la formación de mareas rojas, incluyendo la salinidad, la temperatura del agua, las concentraciones de nutrientes y la disponibilidad de luz (McGaraghan et al., 2012; California Ocean Science Trust, 2016).

Estas mareas suelen ser inocuas y poco frecuentes cuando ocurren en áreas con una tasa alta de intercambio de agua o donde no se emplea la acuicultura a gran escala. Sin embargo, en algunos casos, pueden considerarse un problema cuando causan impactos a nivel socioeconómico y afectan el comercio y el turismo. Pueden llegar, incluso, a generar un riesgo para la salud pública, particularmente si las floraciones son producidas por especies nocivas que representan un peligro para los organismos, incluyendo el ser humano, ya que algunas de ellas tienen la capacidad de producir toxinas potentes (Sar et al., 2002; Hallegraeff et al., 2004; Reguera et al., 2011, 2016).

En Colombia, los eventos de mareas rojas han sido evidentes por años en el ámbito local, en zonas costeras, pero la mayoría de esta información no es pública. Sin embargo, se han divulgado algunos reportes sobre la presencia de microalgas potencialmente nocivas y el impacto negativo producido por las floraciones algales nocivas (FAN) (Mancera-Pineda et al., 2009, 2014; Rodríguez et al., 2010; Arbeláez et al., 2017; Ruiz y Mancera-Pineda, 2019). En los últimos años, se ha observado un incremento en la frecuencia de aparición de mareas rojas en la zona costera del departamento del Magdalena (Colombia), particularmente en la región de Santa Marta (Invemar, 2010, 2015a, 2015b, 2017a, 2017b; Malagón y Perdomo, 2013). Por esta razón, el presente estudio tiene como objetivos analizar la posible influencia de las variables ambientales y climáticas en la aparición de los eventos de mareas rojas ocurridas entre 2010 y 2017 y tratar de identificar patrones temporales de ocurrencia.

\section{INTRODUCTION}

Red tides are natural phenomena that normally cause changes in the color of the water as a result of the increase in the size, density, or accumulation of pigmented planktonic organisms, which include microalgae, cyanobacteria, and microzooplankton ciliates. These events occur in different parts of the world and their apparent growth in both frequency and intensity, in recent decades, is increasingly evident on a global scale (Sar et al., 2002; Hallegraeff et al., 2004). Some studies indicate that several factors influence the formation of red tides, including salinity, water temperature, nutrient concentrations, and light availability (McGaraghan et al., 2012; California Ocean Science Trust, 2016).

These tides are usually harmless and infrequent when they occur in areas with a high rate of water exchange or where large-scale aquaculture is not used. However, in some cases, they can be considered a problem when they cause socio-economic impacts and affect trade and tourism. They can even generate a risk to public health, particularly if the blooms are produced by harmful species that represent a danger to organisms, including humans, as some of them can produce powerful toxins (Sar et al., 2002; Hallegraeff et al., 2004; Reguera et al., 2011, 2016).

In Colombia, red tide events have been evident for years at the local level in coastal areas, but most of this information is not public. However, some reports have been disclosed on the presence of potentially harmful microalgae and the negative impact produced by harmful algal blooms (HAP) (Mancera-Pineda et al., 2009, 2014; Rodríguez et al., 2010; Arbeláez et al., 2017; Ruiz and Mancera-Pineda, 2019). In recent years, an increase in the frequency of the appearance of red tides has been observed in the coastal zone of the Magdalena department (Colombia), particularly in the Santa Marta region (Invemar, 2010, 2015a, 2015b, 2017a, 2017b; Malagón and Perdomo, 2013). For this reason, the present study aims to analyze the possible influence of environmental and climatic variables on the appearance of red tide events that occurred between 2010 and 2017 and to try to identify temporal patterns of occurrence.

\section{STUDY AREA}

Santa Marta is located in the northeastern portion of the Colombian Caribbean $\left(11^{\circ} 15^{\prime}-22^{\prime} \mathrm{N}\right.$ and $73^{\circ} 57^{\prime}-74^{\circ} 12^{\prime}$ W) (Figure 1; Díaz et al., 2000), in the area of influence 


\section{ÁREA DE ESTUDIO}

Santa Marta se encuentra ubicada en la porción nororiental del Caribe colombiano $\left(11^{\circ} 15^{\prime}-22^{\prime} \mathrm{N}\right.$ y $73^{\circ} 57^{\prime}$ $74^{\circ} 12^{\prime}$ W) (Figura 1; Díaz et al., 2000), en el área de influencia de uno de los ecosistemas más estratégicos del país: la Sierra Nevada de Santa Marta, declarada por la Unesco como Reserva de la Biosfera desde 1979. La región incluye aproximadamente diez bahías que representan diversos ecosistemas, las cuales, en su mayoría, están ubicadas en el Parque Nacional Natural Tayrona (PNNT), una de las áreas protegidas del Caribe colombiano.

El área urbana que integra la bahía de Santa Marta presenta una población de aproximadamente 507000 habitantes (Cámara de Comercio de Santa Marta, 2018). En esta región predominan las actividades portuarias y turísticas, las cuales han experimentado un rápido incremento y se han convertido en el ingreso económico más importante de la of one of the country's most important ecosystem strategic points: The Sierra Nevada de Santa Marta, declared by UNESCO as a Biosphere Reserve since 1979. The region includes approximately ten bays that represent diverse ecosystems, most of which are located in the Tayrona National Natural Park (PNNT), one of the protected areas of the Colombian Caribbean.

The urban area that makes up the bay of Santa Marta has a population of approximately 507000 inhabitants (Santa Marta Chamber of Commerce, 2018). In this region, port and tourist activities predominate, which have experienced a rapid increase and have become the most important economic income of the city, along with local commerce and fishing, in order of importance (VegaSequeda et al., 2008).

The region's climate is governed by the climatic pattern of the Colombian Caribbean coast: a dry season

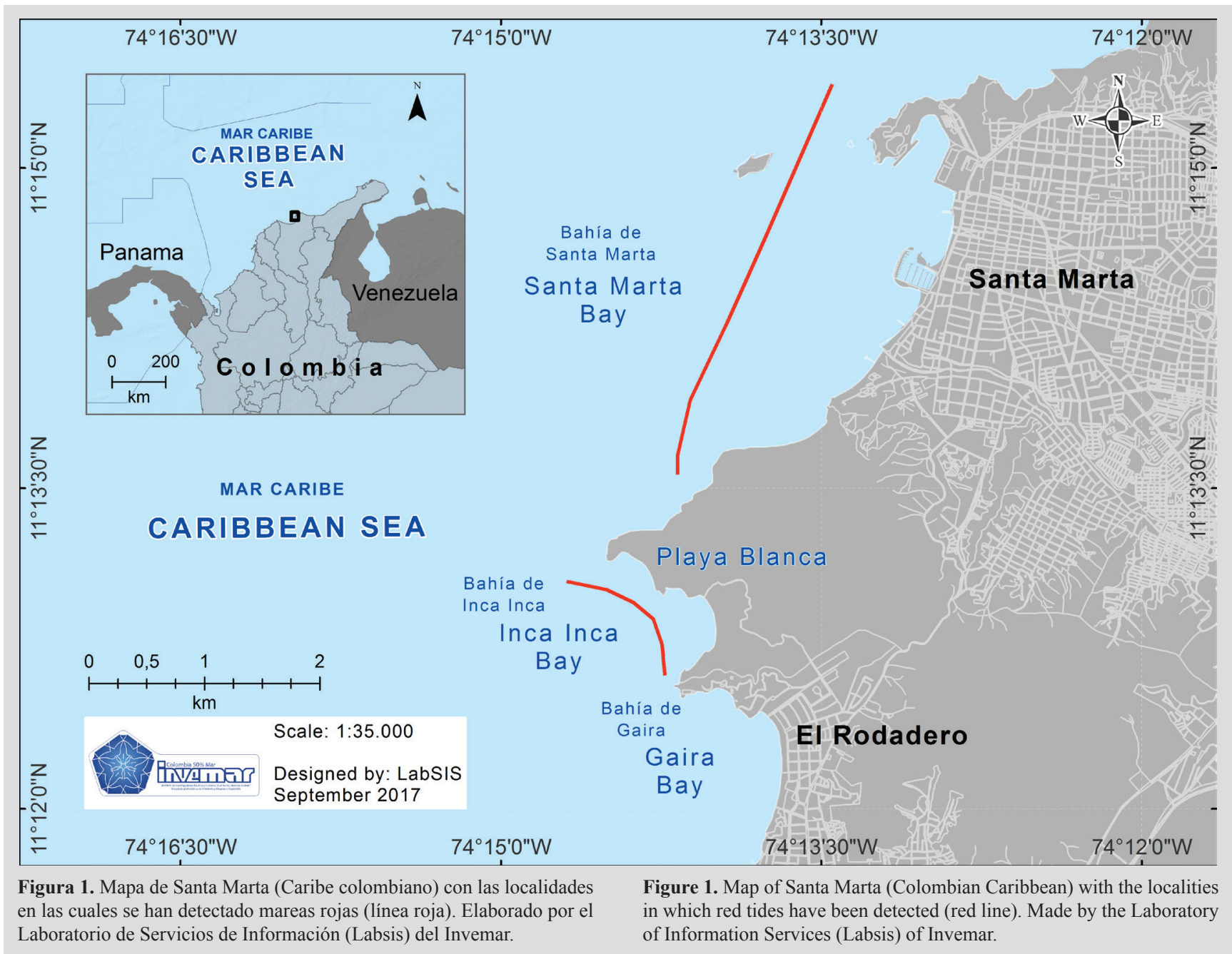


ciudad, junto con el comercio y la pesca local, en orden de importancia (Vega-Sequeda et al., 2008).

El clima de la región se encuentra regido por el patrón climático de la costa Caribe colombiana: una época seca de diciembre a abril y una época de lluvias de mayo a noviembre. Sin embargo, en detalle, se han descrito cuatro épocas climáticas: seca mayor (de diciembre a abril), en la cual la presencia de los vientos alisios del norte genera eventos de surgencia, así como disminución de la temperatura del agua de mar $\left(20-25{ }^{\circ} \mathrm{C}\right)$ e incremento de la salinidad (>38) y de la intensidad del oleaje; lluviosa menor (de mayo a junio), que se caracteriza por una leve disminución de los vientos alisios y la aparición de precipitaciones ligeras; seca menor o "veranillo de San Juan" (de julio a agosto), cuya característica principal es la intensificación de los vientos alisios, que vuelven a ser dominantes pero con menor fuerza, y lluviosa mayor (de septiembre a noviembre), época en la cual se incrementan las precipitaciones (más del $65 \%$ del volumen anual), desaparecen los vientos alisios, tiende a aumentar la temperatura del mar $\left(27-29^{\circ} \mathrm{C}\right)$, disminuye la salinidad del agua $(<34)$ y se acrecienta la carga de sedimentos, lo cual a su vez aumenta la turbidez del agua a causa del incremento en aportes continentales (Ramírez, 1983; Bula-Meyer, 1985; Díaz et al., 2000; Garzón-Ferreira y Díaz, 2003; RodríguezRamírez y Garzón-Ferreira, 2003; Franco-Herrera, 2005). Cabe resaltar que este patrón puede variar, particularmente al haber influencia de eventos climáticos como el fenómeno de La Niña y El Niño (Franco-Herrera, 2005; Montealegre, 2014).

En cuanto a la hidrodinámica, la bahía de Santa Marta se ve influenciada principalmente por dos tipos de macrocorrientes: la corriente del Caribe, formada por la acción de los vientos alisios durante la época seca, y la contracorriente Panamá-Colombia (durante el período de lluvias), proveniente del suroeste de la cuenca del Caribe. Ambas macrocorrientes regulan parcialmente los patrones de circulación superficial local dentro de las bahías ubicadas en la región del Magdalena (Franco-Herrera, 2005). Así mismo, la bahía de Santa Marta recibe aportes continentales atribuidos no solo a la escorrentía, sino también a la desembocadura del río Manzanares, el cual cruza la ciudad y descarga sus aguas directamente en el sector sur de la bahía. from December to April and a rainy season from May to November. However, in detail, four climatic seasons have been described: major dry (from December to April), in which the presence of north trade winds generates upwelling events, as well as a decrease in seawater temperature (20$25^{\circ} \mathrm{C}$ ) and increase in salinity ( $\left.>38\right)$ and wave intensity; less rainy (from May to June), characterized by a slight decrease in the trade winds and the appearance of light rainfall; minor dry season or "veranillo de San Juan" (from July to August), whose main characteristic is the intensification of the trade winds, which are again dominant but with less force, and more rainy (from September to November), which increases rainfall (more than $65 \%$ of the annual volume), the trade winds disappear, the sea temperature tends to increase (27$\left.29^{\circ} \mathrm{C}\right)$, the salinity of the water decreases $(<34)$ and the sediment load increases, which in turn increases the turbidity of the water due to the increase in continental contributions (Ramírez, 1983; Bula-Meyer, 1985; Díaz et al., 2000; Garzón-Ferreira and Díaz, 2003; Rodríguez-Ramírez and Garzón-Ferreira, 2003; Franco-Herrera, 2005). It should be noted that this pattern may vary, particularly due to the influence of climatic events such as the La Niña and El Niño phenomena (Franco-Herrera, 2005; Montealegre, 2014).

Regarding hydrodynamics, the Bay of Santa Marta is mainly influenced by two types of macrocurrents: The Caribbean current, formed by the action of the trade winds during the dry season, and the Panama-Colombia countercurrent (during the period of rains), coming from the southwest of the Caribbean basin. Both macrocurrents partially regulate local surface circulation patterns within bays located in the Magdalena region (FrancoHerrera, 2005). Likewise, the bay of Santa Marta receives continental contributions attributed not only to runoff but also to the mouth of the Manzanares River, which crosses the city and discharges its waters directly into the southern sector of the bay.

\section{MATERIALS AND METHODS}

The biological and physicochemical parameter information was collected during six red tide events that occurred in the bays of Santa Marta and Gaira between 2010 and 2017 (Invemar, 2010, 2015a, 2015b, 2017a, 2017b; Malagón and Perdomo, 2013). To define the characteristics 


\section{MATERIALES Y MÉTODOS}

La información biológica y de parámetros fisicoquímicos fue recopilada durante seis eventos de mareas rojas ocurridos en las bahías de Santa Marta y de Gaira entre 2010 y 2017 (Invemar, 2010, 2015a, 2015b, 2017a, 2017b; Malagón y Perdomo, 2013). Para determinar las características del agua durante estos eventos se hicieron observaciones y se identificó la dispersión de los parches rojizos. Una vez ubicados los parches, se establecieron de tres a cuatro puntos de muestreo para cada evento, en los cuales se midieron aspectos como temperatura del agua, salinidad, oxígeno disuelto y $\mathrm{pH}$, y se recolectaron muestras de un litro de agua para realizar el análisis de nutrientes inorgánicos disueltos (nitrógeno y fósforo). Estas muestras se depositaron en botellas plásticas lavadas previamente y se transportaron al laboratorio para realizar los análisis correspondientes de acuerdo con las metodologías establecidas (Strickland y Parsons, 1972; APHA et al., 2012).

Con el propósito de establecer si el cambio en la coloración del agua era causado por la floración de organismos microscópicos, en los mismos puntos en los cuales se recolectaron las muestras para el análisis fisicoquímico se tomaron directamente muestras de $500 \mathrm{y}$ $80 \mathrm{~mL}$ de agua superficial $(<1 \mathrm{~m})$. En cada evento, la muestra de $80 \mathrm{~mL}$ se almacenó sin fijar y la de $500 \mathrm{~mL}$ se fijó con lugol neutral en proporción 1/100 (Reguera et al., 2016). Luego, las muestras se transportaron a la Unidad de Laboratorios de Calidad Ambiental Marina (Labcam) del Invemar para su análisis.

Las muestras sin fijador se analizaron inmediatamente para observar las células en vivo. Entre tanto, sobre las muestras fijadas con lugol se llevó a cabo un análisis cuantitativo, para lo cual se sedimentaron por tres horas alícuotas de 1 a $3 \mathrm{~mL}$ de la muestra debido a la alta concentración de células, siguiendo el método de sedimentación de Utermöhl (Reguera et al., 2016); se usó un microscopio invertido para hacer las observaciones (Edler y Elbrächter, 2010).

La identificación de organismos se realizó con base en las guías de Balech (1988) y Vidal (1995, 2010). Por su parte, los datos de precipitaciones (sumatoria mensual) y de temperatura superficial de mar se solicitaron al Instituto de Hidrología, Meteorología y Estudios Ambientales (IDEAM, 2015; estación del aeropuerto Simón Bolívar) mientras que el Índice Oceánico de El Niño (ONI) se consultó en el sitio web de NOAA (2020). of the water during these events, observations were made and the dispersion of the reddish patches was identified. Once the patches were located, three to four sampling points were established for each event, in which aspects such as water temperature, salinity, dissolved oxygen, and $\mathrm{pH}$ were measured, and samples of one liter of water were collected to perform the analysis of dissolved inorganic nutrients (nitrogen and phosphorus). These samples were deposited in previously washed plastic bottles and transported to the laboratory to perform the corresponding analyzes according to established methodologies (Strickland and Parsons, 1972; APHA et al., 2012).

To determine whether the change in the color of the water was caused by the flowering of microscopic organisms, at the same points in which the samples were collected for the physicochemical analysis, samples of 500 and $80 \mathrm{~mL}$ of surface water were taken $(<1 \mathrm{~m})$. In each event, the $80 \mathrm{~mL}$ sample was stored unfixed and the $500 \mathrm{~mL}$ sample was fixed with neutral lugol in a $1 / 100$ ratio (Reguera et al., 2016). The samples were then transported to Invemar's Marine Environmental Quality Laboratories Unit (Labcam) for analysis.

Samples without fixatives were immediately analyzed to observe cells in vivo. A quantitative analysis was carried out on the samples fixed with lugol. Aliquots of 1 to $3 \mathrm{~mL}$ of the sample were sedimented for three hours due to the high concentration of cells, following the Utermöhl sedimentation method (Reguera et al., 2016); an inverted microscope was used to make the observations (Edler and Elbrächter, 2010).

The identification of organisms was carried out based on the Balech (1988) and Vidal (1995, 2010) guidelines. The precipitation data (monthly summation) and sea surface temperature were requested from the Institute of Hydrology, Meteorology and Environmental Studies (IDEAM, 2015; Simón Bolívar airport station) while the El Niño Oceanic Index (ONI) was consulted on the NOAA (2020) webpage.

The ONI index is an El Niño-Southern Oscillation (ENSO) measure used to detect warm and cold events such as El Niño and La Niña, respectively, in the tropical Pacific Ocean. This index is based on the average of three consecutive months of the superficial thermal anomalies of the sea, from measurements in the region of El Niño 3.4 (corresponding to $\left.5{ }^{\circ} \mathrm{N}-5{ }^{\circ} \mathrm{S}, 120-70{ }^{\circ} \mathrm{W}\right)$. Neutral values correspond to those between $\pm 0.5{ }^{\circ} \mathrm{C}$, values above $0.5{ }^{\circ} \mathrm{C}$ indicate El Niño 
El índice ONI es una medida de El Niño-Oscilación del Sur (ENSO) utilizada para detectar eventos cálidos y fríos como El Niño y La Niña, respectivamente, en el océano Pacífico tropical. Este índice se fundamenta en la media de tres meses consecutivos de las anomalías térmicas superficiales del mar, a partir de mediciones en la región de El Niño 3,4 (que corresponde a $5^{\circ} \mathrm{N}-5^{\circ} \mathrm{S}, 120-70^{\circ} \mathrm{W}$ ). Los valores neutrales corresponden a aquellos entre $\pm 0,5{ }^{\circ} \mathrm{C}$, valores superiores a $0,5^{\circ} \mathrm{C}$ indican eventos de El Niño y valores inferiores a $-0,5^{\circ} \mathrm{C}$ indican eventos de La Niña por, al menos, cinco períodos consecutivos (NOAA, 2020).

\section{RESULTADOS}

El dinoflagelado Cochlodinium sp. (= Margalefidinium sp.; Figura 2) fue responsable de las tres mareas rojas detectadas en octubre de 2010, octubre de 2011 (Malagón y Perdomo, 2013) y noviembre de 2015. Los dos primeros eventos se observaron principalmente en la bahía de Santa Marta en tanto que el evento de 2015 se presentó en una bahía aledaña (bahía de Gaira). Estas floraciones se caracterizaron por la presencia de manchas de tono rojizo en el agua, las cuales se mantuvieron alejadas de la línea de costa y a una profundidad no mayor de $2 \mathrm{~m}$. Los parches rojizos presentaron un desplazamiento de sur a norte, asociado con la contracorriente Panamá-Colombia, predominante entre septiembre y noviembre. Este período coincide con la época anual de lluvias, acompañada de ligeros vientos del sureste.

Cochlodinium sp. (= Margalefidinium sp.) fue la especie más representativa entre las microalgas observadas durante los muestreos, con abundancias relativas (AR) superiores a $95 \%$. Los individuos se encontraban aislados o formaban cadenas de cuatro células (Figura 2) y, con menos frecuencia, de ocho células. La densidad máxima $\left(5 \times 10^{6}\right.$ cél $\left.\mathrm{L}^{-1}\right)$ se observó en la bahía de Santa Marta en octubre de 2010. Durante los tres eventos (octubre de 2010, octubre de 2011 y noviembre de 2015), las condiciones ambientales típicas del período de lluvias se caracterizaron por el incremento de las precipitaciones ( $>90 \mathrm{~mm}$ [volumen total por mes]) y el consecuente descenso de los vientos alisios, así como por el incremento del aporte de aguas continentales provenientes del río Manzanares y de otros aportes. Esto último generó una disminución de la salinidad $(<35,5)$ y un aumento en la temperatura del agua $(>29,7$ $\left.{ }^{\circ} \mathrm{C}\right)$ (Tabla 1). events, and values below $-0.5{ }^{\circ} \mathrm{C}$ indicate La Niña events for at least five consecutive periods (NOAA, 2020).

\section{RESULTS}

The dinoflagellate Cochlodinium sp. (= Margalefidinium sp.; Figure 2) was responsible for the three red tides events in October 2010, October 2011 (Malagón and Perdomo, 2013), and November 2015. The first two events were observed mainly in the bay of Santa Marta while the 2015 occurred in a neighboring bay (Bay of Gaira). These blooms were characterized by the presence of reddish spots in the water, which were kept away from the coastline and at a depth no greater than $2 \mathrm{~m}$. The reddish patches showed a displacement from south to north, associated with the Panama-Colombia countercurrent, predominant between September and November. This period coincides with the annual rainy season, accompanied by light winds from the southeast.

Cochlodinium sp. (= Margalefidinium sp.) was the most representative species among the microalgae observed during the samplings, with relative abundances (RA) higher than $95 \%$. The individuals were isolated or formed chains of four cells (Figure 2) and, less frequently, of eight cells. Maximum density $\left(5 \times 10^{6}\right.$ cells $\left.\mathrm{L}^{-1}\right)$ was observed in the bay of Santa Marta in October 2010. During the three events (October 2010, October 2011, and November 2015), the typical environmental conditions of the rainy period were characterized by increased rainfall $(>90 \mathrm{~mm}$ [total volume per month]) and the consequent decrease in the trade winds, as well as the increase in the contribution of inland waters from the Manzanares River and other contributions. The latter generated a decrease in salinity $(<35.5)$ and an increase in water temperature $\left(>29.7^{\circ} \mathrm{C}\right)$ (Table 1).

Three more events were recorded during January 2015, January 2017, and March 2017 attributed to the ciliate Mesodinium cf. rubrum (Figure 3), which formed deep red spots. This study corresponds to the first record of red tides produced by said ciliate on the Colombian Caribbean coast. These organisms reached maximum densities of $5.5 \times 10^{4}$ and $9.2 \times 10^{6}$ cells $\mathrm{L}^{-1}$ and an RA of $90 \%$. The events were evident during the dry season, influenced by trade winds and total rainfall per month less than $0.1 \mathrm{~mm}$. The higher cell density was associated with high phosphate concentrations (> $224 \mu \mathrm{g} \mathrm{L}-1)$, increased salinity (> 36.6), and water temperature lower than $26^{\circ} \mathrm{C}$ (Table 1). 


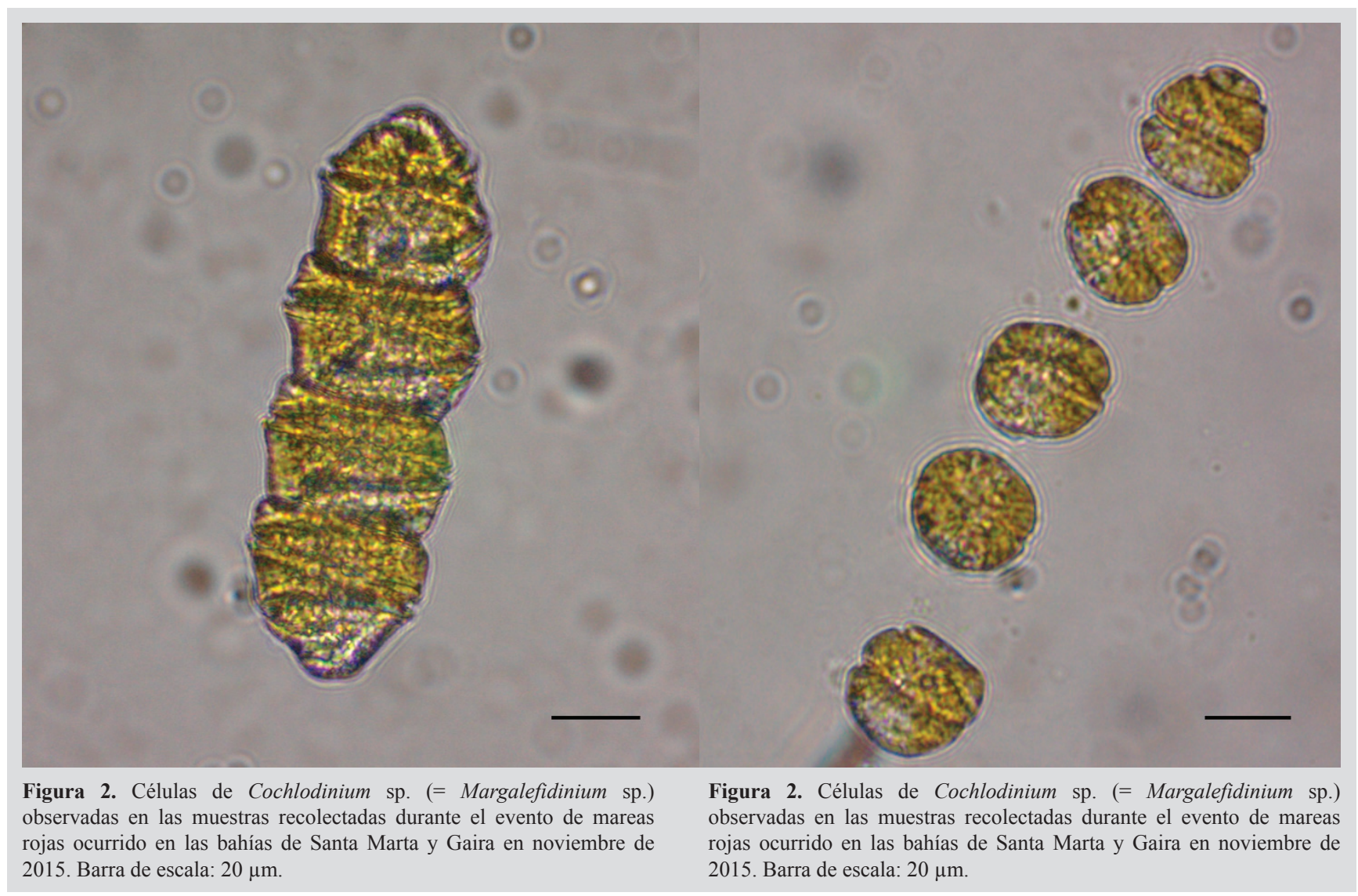

Tabla 1. Variables fisicoquímicas registradas durante los eventos de mareas rojas (valores relacionados con las densidades máximas). Los valores con el símbolo $<$ se refieren a concentraciones de nutrientes por debajo del límite de detección.
Table 1. Physicochemical variables recorded during red tide events (values related to maximum densities). Values with the $<$ symbol refer to nutrient concentrations below the detection limit.

\begin{tabular}{|c|c|c|c|c|c|c|c|c|c|c|}
\hline $\begin{array}{c}\text { Fecha de } \\
\text { mareas rojas/ } \\
\text { Red tide date }\end{array}$ & $\begin{array}{l}\text { Temp. } \\
\left({ }^{\circ} \mathrm{C}\right)\end{array}$ & $\begin{array}{l}\text { Salinidad/ } \\
\text { Salinity }\end{array}$ & pH & $\underset{\left(m g L^{-1}\right)}{\text { OD }}$ & $\begin{array}{c}\mathrm{NO}_{2} \\
\left(\mu \mathrm{g} \mathrm{L}^{-1}\right)\end{array}$ & $\begin{array}{c}\mathrm{NO}_{3} \\
\left(\mu \mathrm{g} \mathrm{L}^{-1}\right)\end{array}$ & $\begin{array}{c}\mathrm{NH}_{4} \\
\left(\mu \mathrm{g} \mathrm{L}^{-1}\right)\end{array}$ & $\begin{array}{c}\mathrm{PO}_{4} \\
\left(\mu \mathrm{g} \mathrm{L}^{-1}\right)\end{array}$ & $\begin{array}{l}\text { Época/ } \\
\text { Season }\end{array}$ & $\begin{array}{l}\text { Responsable/ } \\
\text { Responsible }\end{array}$ \\
\hline 29/oct./2010 & 31.6 & 26.1 & 8.05 & - & 1.8 & 7.8 & 52.3 & 7.4 & Lluvia/ Rain & Cochlodinium \\
\hline 26/oct./2011 & 29.7 & 20 & - & - & - & - & - & - & Lluvia/ Rain & Cochlodinium \\
\hline 9/nov./2015 & 30.1 & 35.5 & 8.05 & 9.28 & $<0.7$ & $<2.1$ & $<3.1$ & $<2.4$ & Lluvia/ Rain & Cochlodinium \\
\hline 15/en./2015 & 25.6 & 36.9 & 8.18 & 6.62 & 1.4 & 3.4 & 62.9 & 6 & Seca/ Dry & Mesodinium \\
\hline 20/en./2017 & 25.9 & 36.6 & 8.33 & 11.3 & 4.1 & - & $<3.1$ & 20.6 & Seca/ Dry & Mesodinium \\
\hline 14/mar./2017 & 25.9 & 36.9 & 8.75 & 8.8 & 1.68 & 2.8 & $<3.1$ & 224 & Seca/ Dry & Mesodinium \\
\hline $\begin{array}{l}\text { Rango para la } \\
\text { época de lluvia/ } \\
\text { Range for } \\
\text { season of rain* }\end{array}$ & $\begin{array}{l}26.6- \\
31.1\end{array}$ & $29.2-36.0$ & $\begin{array}{l}8,13- \\
8.30\end{array}$ & $5.5-7.7$ & $\begin{array}{c}<0.7- \\
7.0\end{array}$ & $\begin{array}{l}<2.1- \\
12.6\end{array}$ & $\begin{array}{c}<3.1- \\
42.0\end{array}$ & $\begin{array}{c}<2.4- \\
6.7\end{array}$ & - & - \\
\hline $\begin{array}{l}\text { Rango para } \\
\text { la época seca/ } \\
\text { Range for epoch } \\
\text { dry }\end{array}$ & $\begin{array}{l}24.0- \\
29.3\end{array}$ & $34.9-37.1$ & $\begin{array}{l}8.03- \\
8.20\end{array}$ & $3.2-8.8$ & $\begin{array}{l}<0.7- \\
4.4\end{array}$ & $\begin{array}{l}<2.1- \\
26.5\end{array}$ & $\begin{array}{c}<3.1- \\
39.0\end{array}$ & $\begin{array}{c}<2.4- \\
12.4\end{array}$ & - & - \\
\hline
\end{tabular}

* Rango histórico de valores registrados en la bahía de Santa Marta de 2014 a 2017, en la época lluviosa y seca. Datos del monitoreo de microalgas nocivas en Colombia realizado por el Invemar.

Nota: los números en negrilla indican los valores observados por fuera del rango histórico registrado en la bahía de Santa Marta de 2014 a 2017.
* Historical range of values recorded in the bay of Santa Marta from 2014 to 2017, in the rainy and dry season. Data from the monitoring of harmful microalgae in Colombia carried out by Invemar.

Note: The numbers in bold indicate the values observed outside the historical range recorded in the bay of Santa Marta from 2014 to 2017. 
Tres eventos más se registraron durante enero de 2015, enero de 2017 y marzo de 2017 atribuidos al ciliado Mesodinium cf. rubrum (Figura 3), el cual formó manchas de color rojo intenso. El presente estudio corresponde al primer registro de mareas rojas producido por dicho ciliado en las costas del Caribe colombiano. Estos organismos alcanzaron densidades máximas de 5,5 × $10^{4}$ y 9,2 $\times 10^{6}$ cél. $\mathrm{L}^{-1}$ y una AR de $90 \%$. Los eventos fueron evidentes durante la época seca, influenciada por vientos alisios y precipitaciones totales por mes inferiores a $0,1 \mathrm{~mm}$. La mayor densidad celular se asoció con altas concentraciones de fosfatos $\left(>224 \mu \mathrm{g} \mathrm{L}^{-1}\right)$, incremento de la salinidad $(>36,6)$ y temperatura del agua inferior a $26^{\circ} \mathrm{C}$ (Tabla 1$)$.
In most of the red tide events recorded in the bay of Santa Marta and other bays close to it, the physicochemical variables such as the concentration of dissolved oxygen in the water and some dissolved inorganic nutrients exceeded the range of concentrations typical of the area (Table 1), this being a key characteristic that allows formulating a hypothesis about the causes of the presence of an algal bloom. During the periods in which the red tides were recorded, climatic fluctuations were more evident on the Colombian Caribbean coast, particularly during 2010-2011 and 2014-2016. These multi-year periods were influenced by two climatic events: a La Niña event during 2010 that lasted until 2011 and in which rainfall increased dramatically

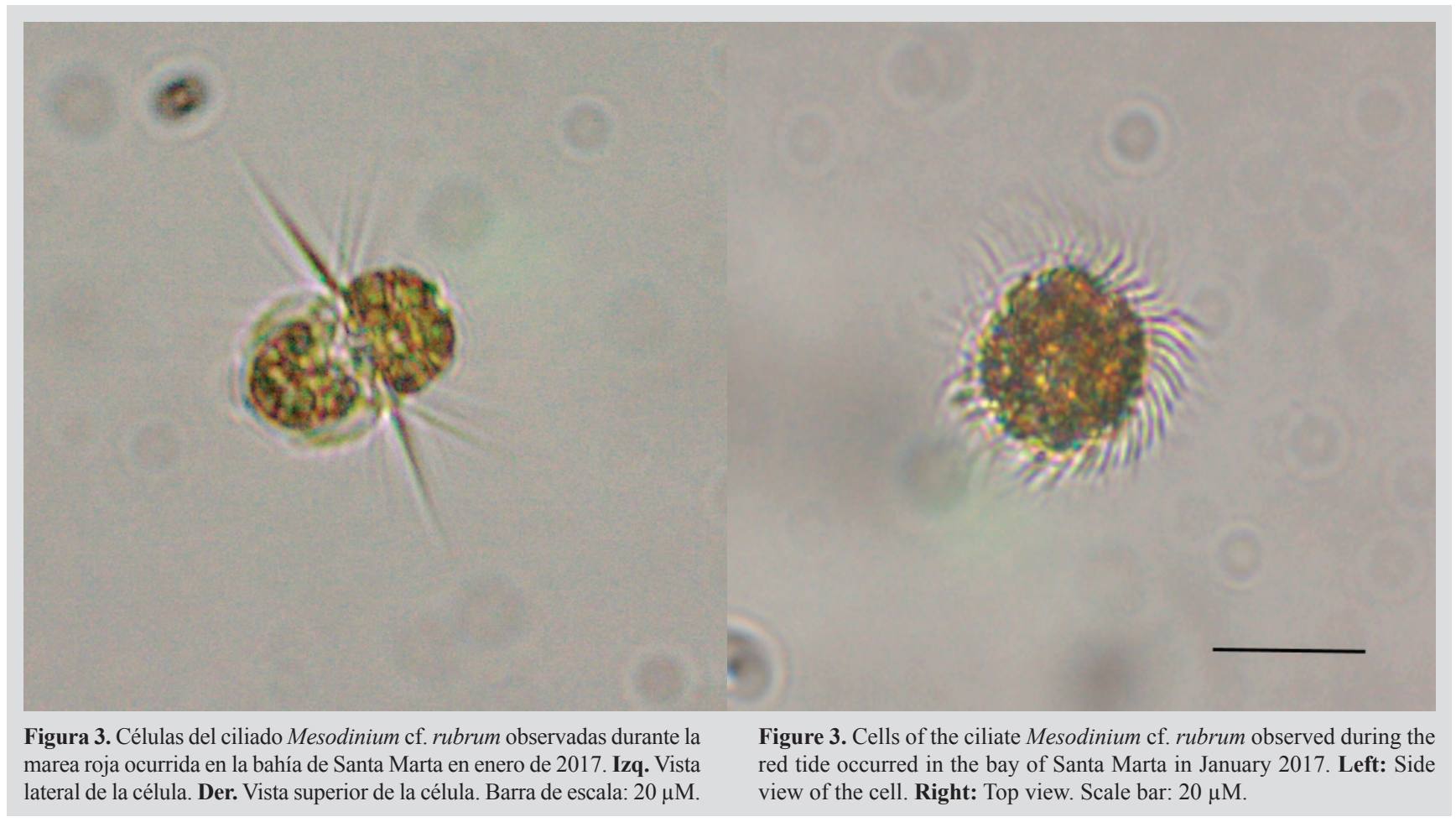

En la mayoría de los eventos de mareas rojas registrados en la bahía de Santa Marta y en bahías cercanas a esta, las variables fisicoquímicas tales como la concentración de oxígeno disuelto en el agua y algunos nutrientes inorgánicos disueltos superaron el rango de concentraciones típicas de la zona (Tabla 1), siendo esta una característica clave que permite formular una hipótesis sobre las causas de la presencia de una floración algal. Durante los períodos en los que se registraron las mareas rojas, las fluctuaciones climáticas fueron más evidentes en la costa del Caribe colombiano, particularmente durante 2010-2011 y 2014-2016. Estos períodos plurianuales se
(> $1000 \mathrm{~mm})$ and an El Niño event, which began in 2014 with moderate intensity, strengthened in 2015, and lasted until mid-2016 (IDEAM, 2015; UNGRD, 2016).

It is worth mentioning that, despite the strong drought prevailing in 2015, during November of this year, the month in which one of the red tide occurred, there was an increase in rainfall in Santa Marta (IDEAM), which exceeded $139 \mathrm{~mm}$. Analyzing the recorded red tide events and the ONI index as the main indicator to monitor El Niño and La Niña events, it becomes clear that the blooms of Cochlodinium sp. (= Margalefidinium sp.) occurred during 
vieron influenciados por dos eventos climáticos: un evento de La Niña durante 2010 que se mantuvo hasta 2011 y en el cual las precipitaciones incrementaron drásticamente (>1000 mm) y un evento de El Niño, que inició en 2014 con intensidad moderada, se fortaleció en 2015 y se prolongó hasta mediados de 2016 (IDEAM, 2015; UNGRD, 2016).

Cabe mencionar que, a pesar de la fuerte sequía predominante en 2015, durante noviembre de ese año, mes en el cual se presentó una de las mareas rojas, se registró un incremento de las precipitaciones en Santa Marta (IDEAM), las cuales superaron $139 \mathrm{~mm}$. Analizando los eventos de mareas rojas registrados y el índice ONI como indicador principal para monitorear los eventos de El Niño y La Niña, se hace evidente que las floraciones de Cochlodinium sp. (= Margalefidinium sp.) ocurrieron durante años influenciados por eventos climáticos moderados-fuertes, con valores ONI superiores a $\pm 1,0{ }^{\circ} \mathrm{C}$. Por su parte, las floraciones causadas por Mesodinium cf. rubrum se presentaron durante años neutrales, con valores inferiores a $\pm 0,5^{\circ} \mathrm{C}$ (Figura 4). years influenced by moderate-strong climatic events, with ONI values higher than $\pm 1.0^{\circ} \mathrm{C}$. On the other hand, the blooms caused by Mesodinium cf. rubrum occurred during neutral years, with values below $\pm 0.5^{\circ} \mathrm{C}$ (Figure 4).

\section{DISCUSSION}

A total of six red tide events were recorded between 2010 and 2017 in the Magdalena region: Three were produced by the dinoflagellate Cochlodinium sp. (= Margalefidinium sp.) and the other three by the ciliate Mesodinium cf. rubrum. Koray (1984) indicates that cell concentrations in red tides regularly vary from $10^{6}$ cells $\mathrm{L}^{-1}$ to $10^{8}$ cells L ${ }^{-1}$. Even densities higher than $5.0 \times 10^{4}$ cells L ${ }^{-1}$, similar values to those observed in the study area during the blooms of both species.

Red tides produced by Cochlodinium sp. (= Margalefidinium sp.) in October 2010, October 2011, and November 2015, during the rainy season in the Magdalena

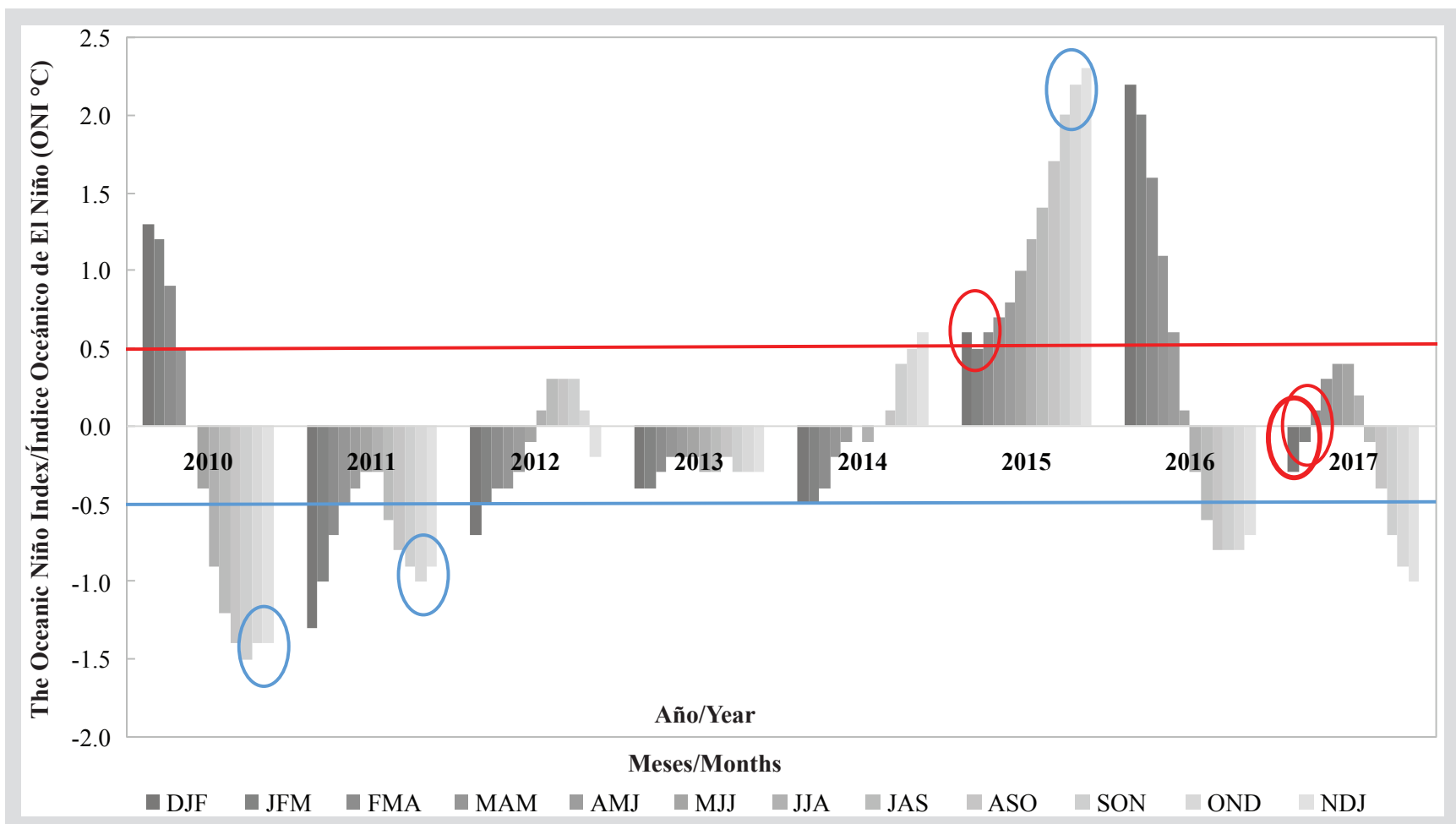

Figura 4. Índice ONI calculado entre 2010 y 2017. Eventos climáticos superiores a $0,5^{\circ} \mathrm{C}$ se consideran influenciados por el fenómeno de El Niño mientras que eventos inferiores a $-0,5^{\circ} \mathrm{C}$ se consideran influenciados por el fenómeno de La Niña. Valores superiores a $\pm 1,5^{\circ} \mathrm{C}$ indican eventos climáticos fuertes. Los círculos azules corresponden a las mareas rojas de Cochlodinium sp. (= Margalefidinium sp.); los círculos rojos, a las de Mesodinium cf. rubrum ocurridas en la bahía de Santa Marta y en bahías aledañas.
Figure 4. ONI index was calculated between 2010 and 2017. Climatic events above $0.5^{\circ} \mathrm{C}$ are considered influenced by the El Niño phenomenon while events below $-0.5{ }^{\circ} \mathrm{C}$ are considered influenced by the La Niña phenomenon. Values greater than $\pm 1.5^{\circ} \mathrm{C}$ indicate strong climatic events. The blue circles correspond to the red tides of Cochlodinium sp. (= Margalefidinium sp.); the red circles, to those of Mesodinium cf. rubrum occurred in the bay of Santa Marta and neighboring bays. 


\section{DISCUSIÓN}

Se registró un total de seis eventos de mareas rojas entre 2010 y 2017 en la región del Magdalena: tres fueron producidos por el dinoflagelado Cochlodinium sp. (= Margalefidinium sp.) y los otros tres por el ciliado Mesodinium cf. rubrum. Koray (1984) indica que regularmente las concentraciones de células en las mareas rojas varían de $10^{6}$ cél. $\mathrm{L}^{-1}$ a $10^{8}$ cél. $\mathrm{L}^{-1}$. Incluso, se alcanzan densidades superiores a 5,0 $\times 10^{4}$ cél. $\mathrm{L}^{-1}$, valores similares a los observados en el área de estudio durante las floraciones de ambas especies.

Las mareas rojas producidas por Cochlodinium sp. (= Margalefidinium sp.) en octubre de 2010, octubre de 2011 y noviembre de 2015, durante la época de lluvias en el Magdalena, reflejan un comportamiento reiterativo en la proliferación de este dinoflagelado en el área, particularmente durante años en los que se presentaron eventos climáticos moderados-fuertes (negativos y positivos). Lo anterior podría mostrar la preferencia de estos dinoflagelados por condiciones extremas relacionadas principalmente con altas temperaturas $\left(>29,7^{\circ} \mathrm{C}\right)$ del agua y disminución de la salinidad $(<35)$.

Morse et al. (2013) han observado floraciones repetitivas producidas por la especie Cochlodinium polykrikoides (= Margalefidinium polykrikoides) en la bahía de Chesapeake, en los Estados Unidos (océano Atlántico). Los autores indican que estas mareas rojas se originan en las desembocaduras de los ríos cuando la temperatura del agua aumenta durante los períodos de vientos débiles y bajas concentraciones de nutrientes. Similar a lo observado en la bahía de Santa Marta, la floración de C. polykrikoides en la bahía de Chesapeake y la ensenada de La Paz, golfo de California, coincidió con períodos de lluvia después de un prolongado período de sequía de verano. En estos eventos, el aporte de aguas continentales no solo fertilizó las aguas, sino que también generó gradientes verticales de densidad y temperatura que favorecieron la estabilidad de la columna de agua y crearon las condiciones adecuadas para la supervivencia y el crecimiento de C. polykrikoides (Alonso, 2004; Mulholland et al., 2009; López-Cortés et al., 2014). Así mismo, otros autores, incluidos Gárate-Lizárraga et al. (2000, 2004) y Gárate-Lizárraga (2013) en el golfo de California, Anton et al. (2008) en las costas de Malasia y Azanza et al. (2008) en Filipinas, también relacionaron las floraciones de este dinoflagelado con una alta concentración de nutrientes causada por la influencia de la lluvia y los vientos. Por esta razón, se considera que la concentración de nutrientes region, reflect a repetitive behavior in the proliferation of this dinoflagellate in the area, particularly during years in which moderate-strong climatic events (negative and positive) occurred. This could show the preference of these dinoflagellates for extreme conditions mainly related to high water temperatures $\left(>29.7^{\circ} \mathrm{C}\right)$ and decreased salinity $(<35)$.

Morse et al. (2013) have observed repetitive blooms produced by the species Cochlodinium polykrikoides (= Margalefidinium polykrikoides) in the Chesapeake Bay, United States (Atlantic Ocean). The authors indicate that these red tides originate at the river mouths when the water temperature rises during periods of weak winds and low nutrient concentrations. Similar to what was observed in the Bay of Santa Marta, the blooms of $C$. polykrikoides in the Chesapeake Bay and La Paz Inlet, Gulf of California, coincided with periods of rain after a prolonged period of summer drought. In these events, the contribution of continental waters not only fertilized the waters but also generated vertical gradients of density and temperature that favored the stability of the water column and created suitable conditions for the survival and growth of $C$. polykrikoides (Alonso, 2004; Mulholland et al., 2009; López-Cortés et al., 2014). Likewise, other authors, including GárateLizárraga et al. (2000, 2004) and Gárate-Lizárraga (2013) in the Gulf of California, Anton et al. (2008) off the coast of Malaysia, and Azanza et al. (2008) in the Philippines, also related the blooms of this dinoflagellate with a high concentration of nutrients caused by the influence of the rain and winds. For this reason, it is considered that the concentration of nutrients dissolved in the water, as well as the hydrodynamics of the area, has a significant influence on its high densities.

Most of the blooms or red tides produced by C. polykrikoides (= Margalefidinium polykrikoide) in North America have been recorded on the Pacific coast, including the bays of Mexico and Costa Rica and the Gulf of California (Table 2; Freer and Vargas-Montero, 2003; Gárate-Lizárraga and Muñetón-Gómez, 2008; Dorantes-Aranda et al., 2009; Calvo-Vargas and ArguedasRodríguez, 2012; López-Cortés et al., 2014). Some of these blooms have had drastic consequences for various species of fish. In Colombia, considering the information collected by Invemar through the monitoring system of harmful microalgae in the Magdalena region, the genus Cochlodinium (= Margalefidinium) is not usually common in the area: it is only observed when blooms occur. 
disueltos en el agua, así como la hidrodinámica de la zona, tiene una influencia significativa en sus altas densidades.

La mayoría de las floraciones o mareas rojas producidas por $C$. polykrikoides (= Margalefidinium polykrikoide) en América del Norte se han registrado en la costa del Pacífico, incluyendo las bahías de México y Costa Rica y el golfo de California (Tabla 2; Freer y VargasMontero, 2003; Gárate-Lizárraga y Muñetón-Gómez, 2008; Dorantes-Aranda et al., 2009; Calvo-Vargas y ArguedasRodríguez, 2012; López-Cortés et al., 2014). Algunas de estas floraciones han generado consecuencias drásticas para varias especies de peces. En Colombia, considerando la información recolectada por el Invemar mediante el sistema de monitoreo de microalgas nocivas en la región del Magdalena, el género Cochlodinium (= Margalefidinium) no suele ser común en el área: solo se observa al presentarse floraciones.
On the other hand, the red tides produced by Mesodinium cf. rubrum were repetitive during the first months of the year (dry season) when the presence of the trade winds generated the basic conditions for the occurrence of upwelling events in the coastal waters of the Colombian Caribbean region, a process that enriches the surface waters with nutrients like phosphorus and nitrogen, which are reincorporated into the water column from the bottom (Lindholm, 1985; Franco-Herrera, 2005; Jiménez and Gualancaña, 2006). The maximum densities reached by this ciliate during red tides in the Colombian Caribbean exceeded those recorded by other authors during various events that occurred in coastal cities of Chile and Mexico (Table 3). However, some authors recorded maximum densities higher than $2 \times 10^{7}$ (Gárate-Lizárraga et al., 2001, 2002) during the red tides in the Gulf of California (Table 3). This indicates
Tabla 2. Densidades de Cochlodinium (= Margalefidinium) registradas durante diferentes eventos de mareas rojas en la costa Pacífica y el Atlántico medio.
Table 2. Cochlodinium (= Margalefidinium) densities recorded during different red tide events on the Pacific coast and the mid-Atlantic.

\begin{tabular}{|c|c|c|c|c|}
\hline Lugar/ Place & Fecha/ Date & Autores/Authors & $\begin{array}{l}\text { Densidades máximas de } \\
\text { M. rubrum }\left(\text { cél. } \mathbf{L}^{-1}\right) / \\
\text { Maximum densities of } \\
\text { M. rubrum }\left(\text { cells } \mathbf{L}^{-1} \text { ) }\right.\end{array}$ & $\begin{array}{l}\text { Ubicación/ } \\
\text { Location }\end{array}$ \\
\hline $\begin{array}{l}\text { Golfo de Nicoya, Costa Rica/ } \\
\text { Gulf of Nicoya, Costa Rica }\end{array}$ & $\begin{array}{l}\text { Febrero y marzo de } 1979 / \\
\text { February and March } 1979\end{array}$ & Hargraves y Víquez (1981) & $80 \times 10^{6}$ & $\begin{array}{l}\text { Costa Pacífica/ } \\
\text { Pacific Coast }\end{array}$ \\
\hline $\begin{array}{l}\text { Bahía de Banderas, Jalisco-Nayarit } \\
\text { (México)/Bay of Banderas, } \\
\text { Jalisco-Nayarit (Mexico) }\end{array}$ & $\begin{array}{l}\text { Octubre de 2001/ October } \\
2001\end{array}$ & Cortés-Lara (2002) & $3 \times 10^{6}$ & $\begin{array}{l}\text { Costa Pacífica/ } \\
\text { Pacific Coast }\end{array}$ \\
\hline $\begin{array}{l}\text { Bahía de Banderas (México)/ } \\
\text { Bay of Banderas (Mexico) }\end{array}$ & $\begin{array}{l}\text { Septiembre de 2000/ } \\
\text { September } 2000\end{array}$ & Cortés-Lara (2004) & $1.1 \times 10^{8}$ & $\begin{array}{l}\text { Costa Pacífica/ } \\
\text { Pacific Coast }\end{array}$ \\
\hline Chesapeake Bay (EE. UU./ US) & $\begin{array}{l}\text { Septiembre de 2007/ } \\
\text { September } 2007\end{array}$ & Mulholland et al. (2009) & $>10^{7}$ & $\begin{array}{l}\text { Atlántico medio/ } \\
\text { Mid Atlantic }\end{array}$ \\
\hline Bahía de la Paz, Baja California & Agosto de 2012/ August 2012 & Gárate-Lizárraga (2013) & $1.4 \times 10^{3}$ & $\begin{array}{l}\text { Costa Pacífica/ } \\
\text { Pacific Coast }\end{array}$ \\
\hline $\begin{array}{l}\text { La Paz, golfo de California/ } \\
\text { La Paz, Gulf of California }\end{array}$ & $\begin{array}{l}\text { Octubre de 2012/ October } \\
2012\end{array}$ & López-Cortés et al. (2014) & $8.6 \times 10^{6}$ & $\begin{array}{l}\text { Costa Pacífica/ } \\
\text { Pacific Coast }\end{array}$ \\
\hline
\end{tabular}

Por otra parte, las mareas rojas producidas por Mesodinium cf. rubrum fueron reiterativas durante los primeros meses del año (época seca) cuando la presencia de los vientos alisios generó las condiciones básicas para la ocurrencia de eventos de surgencia en las aguas costeras de la región del Caribe colombiano, proceso que enriquece las aguas superficiales con nutrientes como fósforo y nitrógeno, que se reincorporan en la columna de agua desde el fondo (Lindholm, 1985; Franco-Herrera, 2005; Jiménez y Gualancaña, 2006). Las densidades máximas alcanzadas por este ciliado durante las mareas rojas en el that the densities of $M$. cf. rubrum during the blooms recorded in Santa Marta are within the range of maximums recorded in North America. Also, in January 2013 a red tide of $M$. rubrum was observed in Bahía de las Ánimas, located in Cartagena de Indias (Colombian Caribbean), with maximum densities of $7.3 \times 10^{5}$ cells L ${ }^{-1}$ (Table 3 ).

Lindholm (1985) and Crawford (1989) mention that M. rubrum is a cosmopolitan species that produces occasional blooms in upwelling areas, estuaries, fjords, and temperate coastal waters. The proliferation of M. rubrum 
Caribe colombiano excedieron a las registradas por otros autores durante varios eventos que ocurrieron en ciudades costeras de Chile y México (Tabla 3). Sin embargo, algunos autores registraron densidades máximas superiores a $2 \times 10^{7}$ (Gárate-Lizárraga et al., 2001, 2002) durante las mareas rojas producidas en el golfo de California (Tabla 3). Esto indica que las densidades de $M$. cf. rubrum durante las proliferaciones registradas en Santa Marta están dentro del intervalo de máximos registrados en América del Norte. Además, en enero de 2013 se observó una marea roja de M. rubrum en la bahía de las Ánimas, ubicada en Cartagena de Indias (Caribe colombiano), con densidades máximas de $7,3 \times 10^{5}$ cél. $\mathrm{L}^{-1}$ (Tabla 3 ).

Lindholm (1985) y Crawford (1989) mencionan que $M$. rubrum es una especie cosmopolita que produce floraciones ocasionales en zonas de surgencia, estuarios, fiordos y aguas costeras templadas. Las proliferaciones de M. rubrum también se han registrado en diferentes costas del mundo, incluyendo Estados Unidos (Johnson et al., 2013), Inglaterra (Kifle y Purdie, 1993; Williams, 1996) y Brasil (De Oliveira, 2004), entre otros. has also been recorded on different coasts of the world, including the United States (Johnson et al., 2013), England (Kifle and Purdie, 1993; Williams, 1996), and Brazil (De Oliveira, 2004), among others.

Red tides are recurrent in the bay of Santa Marta and nearby sectors and, so far, have not represented an apparent risk to public health or other organisms. However, some species of the genus Cochlodinium (= Margalefidinium) have caused a high number of deaths of marine animals in other coastal countries due to their hemolytic activity and the production of oxidizing compounds $(\mathrm{ROS}=$ reactive oxygen species). Although its toxicity is not clear and, to date, there is controversy around its mechanism of action (Kim et al., 2002; Gobler et al., 2008), some studies have confirmed its adverse effects that include hemolysis, osmoregulatory alteration, and asphyxia of organisms due to mucus production (Lee, 1996; Kim et al., 1999, 2000, 2002). For this reason, the species Cochlodinium polyclicoides (= Margalefidinium polykrikoides) is included in the Unesco IOC taxonomic reference list as a toxinproducing species.
Tabla 3. Densidades de Mesodinium cf. rubrum registradas durante diferentes eventos de mareas rojas en la costa Caribe y Pacífica (modificado de Gárate-Lizárraga et al., 2002).
Table 3. Densities of Mesodinium cf. rubrum recorded during different red tide events on the Caribbean and Pacific coast (modified from GárateLizárraga et al., 2002).

\begin{tabular}{|c|c|c|c|c|}
\hline Lugar/ Place & Fecha/ Date & Autores/ Authors & $\begin{array}{l}\text { Densidades máximas de } \\
\text { M. rubrum }\left(\text { cél. } \mathrm{L}^{-1}\right) / \\
\text { Maximum densities of } \\
\text { M. rubrum (cell } \mathrm{L}^{-1} \text { ) }\end{array}$ & $\begin{array}{l}\text { Ubicación/ } \\
\text { Location }\end{array}$ \\
\hline $\begin{array}{l}\text { Aysén y Valparaíso/ Aysén and } \\
\text { Valparaíso (Chile) }\end{array}$ & $\begin{array}{l}\text { Febrero de 1978/ February } \\
1978\end{array}$ & Avaria et al. (1999) & $1.3 \times 10^{3}-8.0 \times 10^{5}$ & $\begin{array}{l}\text { Costa Pacífica/ } \\
\text { Pacific Coast }\end{array}$ \\
\hline $\begin{array}{l}\text { Golfo de California, parte central/ } \\
\text { Gulf of California, central part } \\
\text { (México) }\end{array}$ & Junio de 1982/ June 1982 & Hernández-Becerril (1987) & $1 \times 10^{6}$ & $\begin{array}{l}\text { Costa Pacífica/ } \\
\text { Pacific Coast }\end{array}$ \\
\hline $\begin{array}{l}\text { Golfo de California, isla Cerralvo/ } \\
\text { Gulf of California, Cerralvo Island } \\
\text { (México) }\end{array}$ & Abril de 1994/ April 1994 & $\begin{array}{l}\text { Gárate-Lizárraga et al. } \\
\text { (2001) }\end{array}$ & $2.3 \times 10^{7}$ & $\begin{array}{l}\text { Costa Pacífica/ } \\
\text { Pacific Coast }\end{array}$ \\
\hline Mazatlán, Sinaloa (México) & $\begin{array}{l}\text { 1980; marzo de 1995, 1996; } \\
\text { enero-febrero de 1997/ 1980; } \\
\text { March 1995, 1996; January- } \\
\text { February } 1997\end{array}$ & $\begin{array}{l}\text { Cortés-Altamirano (1984) } \\
\text { Cortés-Altamirano y } \\
\text { Alonso-Rodríguez (1997) }\end{array}$ & $8.6 \times 10^{5}-3.5 \times 10^{6}$ & $\begin{array}{l}\text { Costa Pacífica/ } \\
\text { Pacific Coast }\end{array}$ \\
\hline $\begin{array}{l}\text { Golfo de California/ Gulf of } \\
\text { California (México) }\end{array}$ & $\begin{array}{l}\text { Enero-marzo de 1998/ } \\
\text { January-March } 1998\end{array}$ & $\begin{array}{l}\text { Gárate-Lizárraga et al. } \\
\text { (2002) }\end{array}$ & $2.5 \times 10^{5}-2.0 \times 10^{7}$ & $\begin{array}{l}\text { Costa Pacífica/ } \\
\text { Pacific Coast }\end{array}$ \\
\hline $\begin{array}{l}\text { Bahía de Banderas/ Bay of } \\
\text { Banderas, Jalisco-Nayarit } \\
\text { (México) }\end{array}$ & Enero de 2002/ January 2002 & Cortés-Lara (2002) & $6.4 \times 10^{4}-1 \times 10^{6}$ & $\begin{array}{l}\text { Costa Pacífica/ } \\
\text { Pacific Coast }\end{array}$ \\
\hline $\begin{array}{l}\text { Bahía de las Ánimas, Cartagena } \\
\text { (Colombia) }\end{array}$ & Marzo de 2013/ March 2013 & Invemar (2013) & $1.4 \times 10^{5}-7.3 \times 10^{5}$ & $\begin{array}{l}\text { Costa Caribe/ } \\
\text { Caribbean Coast }\end{array}$ \\
\hline
\end{tabular}


Las mareas rojas son recurrentes en la bahía de Santa Marta y en sectores cercanos y, de momento, no han representado un riesgo aparente para la salud pública ni de otros organismos. Sin embargo, algunas especies del género Cochlodinium (= Margalefidinium) han causado un alto número de muertes de organismos marinos en otros países costeros debido a su actividad hemolítica y a la producción de otros compuestos oxidantes $(\mathrm{ROS}=$ reactive oxygen species). Aunque su toxicidad no es clara y, hasta la fecha, existe controversia en torno a su mecanismo de acción (Kim et al., 2002; Gobler et al., 2008), algunos estudios han confirmado sus efectos adversos que incluyen hemólisis, alteración osmorreguladora y asfixia de organismos a causa de la producción de mucus (Lee, 1996; Kim et al., 1999, 2000, 2002). Por tal motivo, la especie Cochlodinium polyclicoides $(=$ Margalefidinium polykrikoides $)$ se encuentra incluida en la lista de referencias taxonómica de la COI de Unesco como especie productora de toxinas.

Por otro lado, las floraciones de Mesodinium cf. rubrum son generalmente inofensivas (Johnson y Stoecker, 2005). En casos extremos se han asociado con la muerte de peces y algunos invertebrados marinos debido a condiciones de hipoxia y anoxia causadas por la disminución en las concentraciones de oxígeno disuelto en el agua (Hayes et al., 1989; Cortés-Lara, 2002) y el taponamiento de sus branquias (Horstman, 1981). Las floraciones de este ciliado también podrían representar un riesgo indirecto considerando que estos organismos son el alimento esencial de los dinoflagelados mixótrofos del género Dinophysis, los cuales producen toxinas diarreicas (DST). Así pues, las floraciones de $M$. cf. rubrum podrían desencadenar el incremento en las densidades de Dinophysis y aumentarían el riesgo de intoxicaciones diarreicas a través de consumo de mariscos expuestos a estas poblaciones.

Adicionalmente, la aparición de mareas rojas en lugares como bahías puede generar inconvenientes de tipo ambiental, puesto que, al tratarse de una concavidad en la línea costera, el flujo de agua en una bahía tiende a ser menor que en el de un sistema abierto y, por lo tanto, la retención de agua es más prolongada y pueden ocurrir situaciones que pongan en peligro el sistema como, por ejemplo, la muerte de organismos marinos por anoxia (Alonso et al., 2016). Así mismo, las mareas rojas pueden generar inconvenientes de tipo socioeconómico, particularmente en sectores con una alta afluencia turística como es el caso de las bahías en la región del Magdalena. Los cambios de color del agua y el fuerte olor a mariscos que se produce pueden no ser
On the other hand, the blooms of Mesodinium cf. rubrum are generally harmless (Johnson and Stoecker, 2005). In extreme cases, they have been associated with the death of fish and some marine invertebrates due to hypoxic and anoxic conditions caused by the decrease in dissolved oxygen concentrations in the water (Hayes et al., 1989; Cortés-Lara, 2002) and the plugging of their gills (Horstman, 1981). The blooms of this ciliate could also represent an indirect risk considering that these organisms are the essential food of the mixotrophic dinoflagellates of the genus Dinophysis, which produces diarrheic shellfish poisoning(DSTs). Thus, the blooms of $M$. cf. rubrum could trigger the growth in Dinophysis densities and increase the risk of diarrheic poisoning through the consumption of shellfish exposed to these populations.

Furthermore, the appearance of red tides in places such as bays can generate environmental problems, since, being a concavity in the coastline, the flow of water in a bay tends to be less than in an open system and, therefore, water retention is longer and situations may occur that endanger the system, such as the death of marine organisms by anoxia (Alonso et al., 2016). Likewise, red tides can generate socio-economic problems, particularly in sectors with a high tourist influx, such as the bays in the Magdalena region. Changes in the color of the water and the strong shellfish smell that occurs may not be pleasant for bathers when the event occurs.

\section{CONCLUSIONS}

High biomass blooms were detected $\left(>10^{6}\right.$ cells $\mathrm{L}^{-1}$, red tides) of Mesodinium cf. rubrum in the dry season (first months of the year) and of Cochlodinium sp. (= Margalefidinium sp.) in the rainy season (October and November). These red tides showed a cyclical pattern of occurrence in the bay of Santa Marta and nearby bays, influenced by the environmental conditions and the climatic variability.

Through the ONI index, it was possible to show that the red tides produced by Mesodinium cf. rubrum occurred in years with the typical climatic conditions of the area, while the tides of Cochlodinium sp. occurred in years with moderate-strong climatic events (La Niña and El Niño), which indicates the preference of these dinoflagellates for extreme environmental conditions.

Although the red tides detected in the bay of Santa Marta and other nearby bays have not been classified 
agradables para los bañistas que se encuentran donde se produce el evento.

\section{CONCLUSIONES}

Se detectaron floraciones de alta biomasa (> $10^{6}$ cél. $\mathrm{L}^{-1}$, mareas rojas) de Mesodinium cf. rubrum en la época seca (primeros meses del año) y de Cochlodinium sp. (= Margalefidinium sp.) en época de lluvias (octubre y noviembre). Estas mareas rojas mostraron un patrón cíclico de ocurrencia en la bahía de Santa Marta y en bahías cercanas, influenciadas por las condiciones ambientales y la variabilidad climática de cada época.

Mediante el índice ONI fue posible evidenciar que las mareas rojas producidas por Mesodinium cf. rubrum ocurrieron en años con condiciones climáticas típicas de la zona, en tanto que las mareas de Cochlodinium sp. ocurrieron durante años con eventos climáticos (La Niña y El Niño) moderados-fuertes, lo cual indica la preferencia de estos dinoflagelados por condiciones ambientales extremas.

Aunque las mareas rojas detectadas en la bahía de Santa Marta y en otras bahías cercanas no se han catalogado como perjudiciales para la salud humana y la de otros organismos, estos eventos deben continuar siendo monitoreados y estudiados para evitar futuros inconvenientes en el área. Esta información, junto con el monitoreo permanente de microalgas potencialmente nocivas en el Magdalena, podría considerarse como un insumo relevante para la construcción de un sistema de alerta temprana de las FAN en la región del Caribe colombiano, el cual ayudaría a las autoridades ambientales del país a tomar medidas cuando ocurran estos eventos.

\section{AGRADECIMIENTOS}

Los autores agradecen al Organismo Internacional de Energía Atómica (OIEA) por su apoyo para llevar a cabo el monitoreo de microalgas nocivas en el Caribe colombiano a través de proyectos regionales. Así mismo, agradecen al Instituto de Investigaciones Marinas y Costeras "José Benito Vives de Andréis" (Invemar) por el apoyo técnico y al Ministerio de Medio Ambiente y Desarrollo Sostenible de Colombia por el apoyo económico. Contribución 1275 del Invemar. as harmful to human and other organisms health, these events must continue to be monitored and studied to avoid future inconveniences. This information, together with the permanent monitoring of potentially harmful microalgae in the Magdalena region, could be considered as a relevant input for the construction of an early warning system for harmful algae blooms (HABs) in the Colombian Caribbean region, which would help the country's environmental authorities to take action when these events occur.

\section{ACKNOWLEDGEMENTS}

The authors thank the International Atomic Energy Agency (IAEA) for its support to carry out the monitoring of harmful microalgae in the Colombian Caribbean through regional projects. Likewise, they thank the Marine and Coastal Research Institute "José Benito Vives de Andréis" (Invemar) for the technical support and to the Ministry of Environment, Housing and Territorial Development of Colombia for economic support. Invemar Contribution 1275 . 


\section{BIBLIOGRAFÍA/LITERATURE CITED}

Alonso, R. 2004. Hidrología y condiciones ambientales que determinan la proliferación de dinoflagelados causantes de mareas rojas en la bahía de Mazatlán, Sin., México. Tesis Ph.D. Ciencias. Centro de Investigaciones Biológicas del Noroeste, S.C. La Paz. 116 p.

Alonso, R., Á. Moreira, S. Méndez, and B. Reguera. 2016. Introduction. 5. In: Reguera, B., R. Alonso, A. Moreira, S. Méndez, and M.Y. Dechraoui-Bottein. (Eds). 2016. Guide for designing and implementing a plan to monitor toxin-producing microalgae. 2nd Ed. IOC Manuals and Guides, (59). Unesco and IAEA, Paris and Vienna. $66 \mathrm{p}$.

Anton, A, P.L. Teoh, S.R. Mohd-Shaleh, and N. Mohammad-Noor. 2008. First occurrence of Cochlodinium blooms in Sabah, Malaysia. Harmful Algae, 7: 331-336.

APHA, AWWA, and WEF. 2012. Standard methods for the examination of water and wastewater. 22. ${ }^{\circ}$ Ed. American Water Works Association, Washington. $1463 \mathrm{p}$.

Arbeláez, N., J.E. Mancera y B. Reguera. 2017. Dinoflagelados epífitos de Thalassia testudinum en dos sistemas costeros del Caribe colombiano. Bol. Investig. Mar. Costeras, 46(2): 9-40.

Avaria, S., M. Cáceres, P. Muñoz, S. Palma y P. Vera. (Eds.). 1999. Plan nacional sobre floraciones de algas nocivas en Chile. Comité Oceanográfico Nacional, Santiago de Chile. 31 p.

Azanza, R.V., L.T. David, R.T. Borja, I.U. Baula, and Y. Fukuyo. 2008. An extensive Cochlodinium bloom along the western coast of Palawan, Philippines. Harmful Algae, 7: 324-330.

Balech, E. 1988. Los dinoflagelados del Atlántico sudoccidental. Ministerio de Agricultura, Pesca y Alimentación, Madrid. 310 p.

Bula-Meyer, G. 1985. Un nuevo núcleo de surgencia en el Caribe colombiano detectado en correlación con las macroalgas. Bol. Ecotrópica, 12 : 2-26.

California Ocean Science Trust. 2016. Framing the science around harmful algal blooms and California fisheries: scientific insights, recommendations and guidance for California. California Ocean Science Trust, Oakland, CA. 20 p.

Calvo-Vargas, E. y M. Arguedas-Rodríguez. 2012. Muestreo de las floraciones algales nocivas (FANs) en el golfo de Nicoya, Puntarenas, Costa Rica. Universidad Nacional, Heredia, Costa Rica. 7 p.

Cámara de Comercio de Santa Marta. 2018. Informe económico: indicadores económicos 2017-2018. Unidad de Desarrollo Competitivo (UDC). Coordinación Proyectos e Investigaciones. Santa Marta. 56 p.

Cortés-Altamirano, R. 1984. Mareas rojas producidas por el ciliado Mesodinium rubrum (Lohman) en el litoral de Mazatlán, Sinaloa, México. Biótica, 9: 259-269.

Cortés-Altamirano, R. y R. Alonso-Rodríguez. 1997. Mareas rojas durante 1997 en la bahía de Mazatlán, Sinaloa, México. Cienc. Mar, 15: 31-37.

Cortés-Lara, M.C. 2002. Primer registro de marea roja del 2002. Bahía de Banderas Jalisco-Nayarit (enero de 2002). Rev. Biomed., 13(3): 229-230. https:// doi.org/10.32776/revbiomed.v13i3.321 20/08/2018.

Cortés-Lara, M.C., R. Cortés-Altamirano y A.P. Sierra-Beltrán. 2004. Presencia de Cochlodinium catenatum (Gymnodiniales: Gymnodiniaceae) en mareas rojas de bahía de Banderas, Pacífico mexicano. Rev. Biol. Trop., 52: 35-49.

Crawford, D.W. 1989. Mesodinium rubrum: the phytoplankter that wasn’t. Mar. Ecol. Prog. Ser., 58: 161-174.

Crawford, D.W. and T. Lindholm, 1997. Some observations on vertical distribution and migration of the phototrophic ciliate Mesodinium rubrum (= Myrionecta rubra) in a stratified brackish inlet. Aquat. Microb. Ecol., 13: 267-274.

De Oliveira, L.A. 2004. A red water caused by Mesodinium rubrum on the coast of Santa Catarina, southern Brazil. Braz. J. Oceanogr., 52(2): 153-161.

Díaz, J. M., L. M. Barrios, M.H. Cendales, J. Garzón-Ferreira, J. Geister, M. López-Victoria, G.H. Ospina, F. Parra-Velandia, J. Pinzón, B. Vargas-Ángel, F.A. Zapata y S. Zea. 2000. Áreas coralinas de Colombia. Ser. Publ. Espec., (5). Invemar, Santa Marta. 176 p.

Dorantes-Aranda, J.J., L.M. García-De la Parra, R. Alonso-Rodríguez, and L. Morquecho. 2009. Hemolytic activity and fatty acids composition in the ichthyotoxic dinoflagellate Cochlodinium polykrikoides isolated from Bahía de La Paz, Gulf of California. Mar. Pollut. Bull., 58: 1401-1405.

Edler, L. and M. Elbrächter. 2010. The Utermöhl method for quantitative phytoplankton analysis: 13-20. In: Karlson, B., C. Cusack, and E. Bresnan. (Eds.) Microscopic and molecular methods for quantitative phytoplankton analysis. IOC Manuals and Guides, (55). Unesco. Paris. 110 p.

Franco-Herrera, A. 2005. Una aproximación a la oceanografía de la ensenada de Gaira: El Rodadero, más allá que un centro turístico. Univ. Jorge Tadeo Lozano, Santa Marta. 58 p.

Freer, E. y M. Vargas-Montero. 2003. Floraciones algales nocivas en la costa pacífica de Costa Rica: toxicología y sus efectos en el ecosistema y salud pública. Acta Med. Costarric., 45(4): 158-164. 
Gárate-Lizárraga, I. 2013. Bloom of Cochlodinium polykrikoides (Dinophyceae: Gymnodiniales) in Bahía de La Paz, Gulf of California. Mar. Pollut. Bull., 67: $217-222$.

Gárate-Lizárraga, I. y M.S. Muñetón-Gómez. 2008. Los riesgos de las mareas rojas en el Pacífico mexicano. Conversus, 3: 20-23.

Gárate-Lizárraga, I., J.J. Bustillos-Guzmán, L.M. Morquecho, and C.H. Lechuga-Deveze. 2000. First outbreak of Cochlodinium polykrikoides in the Gulf of California. Harmful Algae News, 21: 7.

Gárate-Lizárraga, I., M.L. Hernández-Orozco, C. Band-Schmidt, and G. Serrano-Casillas. 2001. Red tides along the coasts of Baja California Peninsula, México 1984 to 2001. Oceánides, 16(2): 127-134.

Gárate-Lizárraga, I., C. Band-Schmidt, R. Cervantes-Duarte y D. Escobedo-Urías. 2002. Mareas rojas de Mesodinium rubrum (Lohmann) Hamburger y Buddenbrock en el golfo de California (invierno de 1998). Hidrobiológica, 12: 15-20.

Gárate-Lizárraga, I., D.J. López-Cortés, J.J. Bustillos-Guzmán, and F.E. Hernández-Sandoval. 2004. Blooms of Cochlodinium polykrikoides (Gymnodiniaceae) in the Gulf of California, México. Rev. Biol. Trop., 52(Suppl. 1): 51-58.

Garzón-Ferreira, J. and J.M. Díaz. 2003. The Caribbean coral reefs of Colombia: 275-301. In: Cortés, J. (Ed.). Latin American Coral Reefs. Elsevier Science B.V., Amsterdam. 508 p.

Gobler, C.J., D.L. Berry, O.R. Anderson, A. Burson, F. Koch, B.S. Rodgers, L.K. Moore, J.A. Golesky, B. Allam, P. Bowers, Z.Y. Tang, and R. Nuzzi. 2008. Characterization, dynamics, and ecological impacts of harmful Cochlodinium polykrikoides blooms on eastern Long Island, NY, USA. Harmful Algae, 7: 293-307.

Hallegraeff, G.M., D.M. Anderson, and A.D. Cembella. 2004. Manual on harmful marine microalgae. Monographs on Oceanographic Methodology. Unesco, Paris. $793 \mathrm{p}$.

Hargraves, P.E. and R. Víquez. 1981. The dinoflagellate red tide in Golfo de Nicoya, Costa Rica. Rev. Biol. Trop., 29: 31-38.

Hayes, G.C., D.A. Puerdie, and J.A. Williams. 1989. The distribution of ichtyoplankton in Southampton water in response to low oxygen levels produced by Mesodinium rubrum bloom. J. Fish. Biol., 34: 811-813.

Hernández-Becerril, D.U. 1987. Un caso de mareas rojas en el golfo de California. Rev. Latinoam. Microbiol., 29: 171-174.

Horstman, D.A. 1981. Reported red-water outbreaks and their effects on fauna of the west and south coasts of South Africa, 1959-1980. Fish. Bull. S. Afr., 15: $71-88$.

IDEAM. 2015. Anuario climatológico 2015. Inst. Hidrol., Meteorol. Est. Ambient., Bogotá. 363 p.

Invemar. 2010. Concepto técnico sobre el evento de florecimiento de microalgas en el área de Santa Marta. CPT-CAM-044-10. Inst. Investig. Mar. Costeras, Santa Marta. $10 \mathrm{p}$.

Invemar. 2013. Concepto técnico sobre el análisis del fitoplancton de cuatro muestras de agua de la bahía de Cartagena tomadas por el CIOH el 27 de marzo de 2013. CTP-CAM-008-13. Inst. Investig. Mar. Costeras, Santa Marta. 6 p.

Invemar. 2015a. Concepto técnico sobre aparición de mancha roja frente a playa Blanca y la bahía de Santa Marta. CPT-CAM-001-15. Inst. Investig. Mar. Costeras, Santa Marta. 18 p.

Invemar. 2015b. Concepto técnico sobre posible evento de floración de microalgas frente a la Playa del Rodadero. CPT-CAM-020-15. Inst. Investig. Mar. Costeras, Santa Marta. 12 p.

Invemar. 2017a. Concepto técnico sobre la mancha roja observada desde la bahía de Santa Marta hasta el sector de Playa Blanca. CPT-CAM-002-17. Inst. Investig. Mar. Costeras, Santa Marta. 12 p.

Invemar. 2017b. Concepto técnico sobre la mancha roja observada entre la bahía de Santa Marta y Taganga. CPT-CAM-008-17. Inst. Investig. Mar. Costeras, Santa Marta. 14 p.

Jiménez, R. y E. Gualancaña. 2006. Floraciones de Mesodinium rubrum en los procesos de surgencia en el pacífico ecuatorial. Acta Oceanogr. Pac., 13(1): 71-78.

Johnson, M.D. and D.K. Stoecker. 2005. Role of feeding in growth and photophysiology of Myrionecta rubra. Aquat. Microb. Ecol., $39: 303-312$.

Johnson, M.D., D.K. Stoecker, and H.G. Marshall. 2013. Seasonal dynamics of Mesodinium rubrum in Chesapeake Bay. J. Plankton Res, $35(4)$ : 877-893. https://doi.org/10.1093/plankt/fbt028

Kifle, D. and D.A. Purdie. 1993. The seasonal abundance of the phototrophic ciliate Mesodinium rubrum in Southampton Water, England. J. Plankton Res., 15(7): 823-833. 
Kim, C.S., S.G. Lee, C.K. Lee, H.G. Kim, and J. Jung. 1999. Reactive oxygen species as causative agents in the ichthyotoxicity of the red tide dinoflagellate Cochlodinium polykrikoides. J. Plankton Res., 21(11): 2105-2115.

Kim, C.S., S.G. Lee, and H.A. Kim. 2000. Biochemical responses of fish exposed to a harmful dinoflagellate Cochlodinium polykrikoides. J. Exp. Mar. Biol. Ecol., 254: 131-141.

Kim, D., T. Oda, T. Muramatsu, D. Kim, Y. Matsuyama, and T. Honjo. 2002. Possible factors responsible for the toxicity of Cochlodinium polykrikoides, a red tide phytoplankton. Comp. Biochem. Physiol. C., 132(4): 415-423. https://doi.org/10.1016/S1532-0456(02)00093-5

Koray, T. 1984. The occurrence of red tide and causative organisms in Izmir Bay, E.U. Fac. Sci. J. Ser. B., 7(1): 75-83.

Lee, J.S. 1996. Bioactive components from the red tide plankton Cochlodinium polykrikoides. J. Kor. Fish. Soc., 29: 165-173.

Lindholm, I. 1985. Mesodinium rubrum: a unique photosynthetic ciliate. Adv. Aq. Microbiol., 3: 1-48.

López-Cortés, D.J., C.J. Band-Schmidt, J.J. Bustillos-Guzmán, F.E. Hernández-Sandoval, A. Mendoza-Flores y E.J. Núñez-Vázquez. 2014. Condiciones ambientales durante un florecimiento de Cochlodinium polykrikoides (Gymnodiniales, Dinophyceae) en la ensenada de La Paz, golfo de California. Rev. Biol. Mar. Oceanogr., 49: 97-110.

Malagón, A. and L.V. Perdomo. 2013. Cochlodinium polykrikoides bloom in the Colombian Caribbean. Harmful Algae News, 47: 14-15.

Mancera-Pineda, J.E., B. Gavio y G. Arencibia. 2009. Floraciones algales nocivas, intoxicación por microalgas e impactos en el desarrollo regional: el caso de San Andrés isla, Caribe colombiano. 46-62. En: Mancera-Pineda, J.E., O. Sierra y S. Pérez. 2009. (Eds). Reserva de Biosfera Seaflower. Problema Ambiental. Cuad. Car. 13, 78 p.

Mancera-Pineda, J.E., M. Montalvo-Talaigua y B. Gavío. 2014. Dinoflagelados potencialmente tóxicos asociados a material orgánico flotante (drift) en San Andrés Isla, Reserva Internacional de la Biosfera - Seaflower. Caldasia, 36: 139-156.

McGaraghan, A., R. Kudela, and K. Negrey, 2012. A primer on California harmful algal blooms: common questions and answers for stakeholders, decision makers, coastal managers, and the education community. http://fisheries.legislature.ca.gov/sites/fisheries.legislature.ca.gov/files/u8/Primer\%20on\%20 HAB $\% 20$ westcoast.pdf 30/05/2018.

Montealegre, J.E. 2014. Actualización del componente meteorológico del modelo institucional del IDEAM sobre el efecto climático de los fenómenos El Niño y La Niña en Colombia como insumo para el Atlas Climatológico. IDEAM, Bogotá. 80 p.

Morse, R.E., M.R. Mulholland, W.S. Hunley, S. Fentress, M. Wiggins, and J.L. Blanco-García. 2013. Control on the initiation and development of blooms of the dinoflagellate Cochlodinium polykrikoides Margalef in lower Chesapeake Bay and its tributaries. Harmful Algae, 28: 71-82.

Mulholland, M.R., R.E. Morse, G.E. Boneillo, P.W. Bernhardt, K.C. Filippino, L.A. Procise, J.L. Blanco-Garcia, H.G. Marshall, T.A. Egerton, W.S. Hunley, K.A. Moore, D.L. Berry, and C.J. Gobler. 2009. Understanding causes and impacts of the dinoflagellate, Cochlodinium polykrikoides, blooms in the Chesapeake Bay. Estuaries Coast., 32(4): 734-747.

NOAA. 2020. Climate prediction center. Cold \& warm episodes by season. Nat. Oc. Atm. Adm. https://origin.cpc.ncep.noaa.gov/products/analysis_ monitoring/ensostuff/ONI_v5.php 16/02/2020.

Ramírez, G. 1983. Características fisicoquímicas de la bahía de Santa Marta (agosto, 1980-julio, 1981). An. Inst. Investig. Mar. Punta Betín, $13:$ 111-121.

Reguera, B., R. Alonso, A. Moreira y S. Méndez. 2011. Guía para el diseño y puesta en marcha de un plan de seguimiento de microalgas productoras de toxinas. Manuales y guías de la COI. Unesco y OIEA, París y Viena. 59 p.

Reguera, B. R. Alonso, A. Moreira, S. Méndez, and M.Y. Dechraoui-Bottein (Eds). 2016. Guide for designing and implementing a plan to monitor toxinproducing microalgae. 2nd Ed. IOC Manuals and Guides (59). Unesco and IAEA, Paris and Vienna. 66 p.

Rodríguez, A., J.E. Mancera-Pineda, and B. Gavio. 2010. Survey of benthic dinoflagellates associated to beds of Thalassia testudinum in San Andrés Island, Seaflower Biosphere Reserve, Caribbean Colombia. Acta. Biol. Colomb., 15(2): 229-246.

Rodríguez-Ramírez, A. y J. Garzón-Ferreira. 2003. Monitoreo de arrecifes coralinos, pastos marinos y manglares en la bahía de Chengue (Caribe colombiano): 1993-1999. Ser. Publ. Espec., (8). Invemar, Santa Marta. 170 p.

Ruiz, A. and J.E. Mancera-Pineda. 2019. Potentially toxic dinoflagellates associated to seagrass on isla de Barú, Colombian Caribbean, during El Niño 2015. Acta. Biol. Colomb., 24: 109-117.

Sar, E.A., M.E. Ferrario y B. Reguera. (Eds.). 2002. Floraciones algales nocivas en el cono sur americano. Inst. Esp. Oceanogr., Madrid. 311 p.

Strickland, D.H. and T.R. Parsons. 1972. A practical handbook of seawater analysis. 2. ${ }^{\circ}$ Ed. Fish. Res. Board Can. Bull. 157. 310 p.

UNGRD. 2016. Fenómeno El Niño, análisis comparativo 1997-1998//2014-2016. Unid. Nal. Gestión Riesgo Desastres, Bogotá. 143 p. 
Vega-Sequeda, J., A. Rodríguez-Ramírez, M.C. Reyes-Nivia y R. Navas-Camacho. 2008. Formaciones coralinas del área de Santa Marta: estado y patrones de distribución espacial de la comunidad bentónica. Bol. Investig. Mar. Costeras, 37(2): 87-105.

Vidal, L.A. 1995. Estudio del fitoplancton en el sistema lagunar estuarino tropical Ciénaga Grande de Santa Marta, Colombia, durante el año 1987. Tesis M.Sc. Biol. Universidad Nacional de Colombia, Bogotá. 207 p.

Vidal, L.A. 2010. Manual del fitoplancton hallado en la Ciénaga Grande de Santa Marta y cuerpos de agua aledaños. Fund. Univ. Bogotá Jorge Tadeo Lozano, Bogotá. 384 p.

Williams, J.A. 1996. Blooms of Mesodinium rubrum in Southampton Water: do they shape mesozooplankton distribution? J. Plankton Res., 18(9): 16851697.

RECIBIDO/RECEIVED: 22/10/2019

ACEPTADO/ACCEPTED: 12/08/2020 